\title{
The Contribute of Minero-Petrographic and Chemical Studies in Archeoceramics
}

\author{
Germana Barone* \\ Department of Biological, University of Catania, Italy
}

Submission: October 03, 2017; Published: November 10, 2017

*Corresponding author: Germana Barone, Department of Biological, University of Catania, Italia, Tel: 5795129 Catania, Italy, Email: gbarone@unict.it

\section{Opinion}

Ceramics are the most diffused artifacts in archaeological context; being a daily-use artifact, these remains usually offer the possibility to investigate a wide range of dynamics, involving commercial routes, habits, moods, as well technological knowledge of an ancient societies. The study of archaeological ceramics often involves different disciplines, namely from archaeology to physic, chemist and geology. The numerous questions related to archaeological artifacts, usually synthesized in the well known questions about how, where and when an artifact was produced imply often not only the contribute of scientific expertise, but also the application of methods able to investigate materials at different scale of observation. In the case of ceramics, this require the application of multi-disciplinary and multi-scale techniques, to inspect materials from macroscale to micro-scale.

The basic approach to archaeological ceramics consists in the typological classification, allowing to discriminate materials on the basis of context, shape, decoration, style, color and grain size. Beside some rare and peculiar cases, for which a ceramic artifact could be related to a specific workshop and/or geographic and historical context, the only naked-eye observation, however is not enough to characterize raw materials, as well obtain information on manufacture technology and provenance. Even a ceramic could appears like homogenous, being the result of a more or less accurate mixing of clayey material and eventually tempers, processes as manufacture, firing, use and burial conditions often determine a range of variability into the ceramic paste which characterization can be achieved by petrographic, mineralogical and chemical studies, also coupled with more advanced methods.

In the case of coarse-grained ceramics, characterized by the occurrence of tempers usually consisting in polycrystalline rock fragments, the thin section analysis can offer quite relevant effort in provenance studies; in fact, the presence of mineral assemblages typical of a geographic and geologic context represents a quite certain signature for correct attribution. This is the case, for examples, of Sicilian productions exhibiting metamorphic rocks fragments as tempers, for which a Peloritane area production can be suggested [1], or the wellknown Pantelleria ware, in which the occurrence of sanidine, pyroxene and aenigmatite are typical of volcanic local rocks [2$3]$. Coupled petrographic and chemical study can address more and more information on provenance, as in the case of mineral chemistry of volcanic pyroxenes, able to discriminate pottery produced by using materials from different volcanic Italian provinces [2] see also the website https://sites.google.com/ site/archaeometrypottery/.

Even if useful to support dissertation on provenance and manufacture, allowing to discriminate fabrics and ceramic groups [4], petrographic observations cannot resolve mineralogy of clayey sediments as well the presence of minerals considered firing temperature indicators [5-6]. To achieve these aims, mineralogical analysis can provide fundamental information, especially if coupled with micro-morphological observation with the support case of chemical data [7]. Of course, the aforementioned approach is not so trivial in the case of finegrained ceramic, in which the absence of tempers prevents provenance hypothesis on the basis of the solely petrographic observations. In this case, chemical analysis and the comparison with reference materials of a certain local production (laboratory tests made with clay sediments, kiln wastes and common ceramic) provides indispensable information [8-9]. The creation of reference groups appears, in this prospective, fundamental for further provenance studies [10].

With these drawbacks, it is quite clear that for a basic knowledge of archaeological ceramics cannot exclude a basic petrographic, mineralogical and chemical characterization. However, the technological advancements and the possibility to perform in deep analysis can of course improve archeological investigations. This is the case of the application of nondestructive and non invasive methods, also portable ones for in situ analysis, on precious and rare artifacts for which questions on decorations can be inspected [11], or the use of advanced techniques able to inspect nanometric texture of ceramics to achieve information on firing processes [12-14]. 


\section{Conclusion}

In conclusion, with this brief overview, we have rapidly flight over the opportunities offered by geosciences to archeoceramic studies, highlighting how the application of an analysis routines cannot disregard aspects as typology and textural features of archeological ceramics, as well possibility to collect representative specimens to analyse or perform in situ non destructive studies.

\section{References}

1. Barone G, Mazzoleni P, Ingoglia C, Vanaria MG (2011a) Archaeometric evidences of the $4^{\text {th }}-2^{\text {nd }}$ century BC amphorae productions in north eastern Sicily. Journal of Archaeological Science 38(11): 3060-3071.

2. Barone G, Belfiore CM, Mazzoleni P, Pezzino A, Viccaro M (2010) A volcanic inclusions based approach for provenance studies of archaeological ceramics: application to pottery from southern Italy. Journal of Archaeological Science 37: 713-726.

3. Barone G, Chowaniec R, Mangioni S, Mazzoleni P, Raneri S (2016) Evaluation of the technological features of late roman cooking ware classes from Akrai (Syracuse, Sicily), Mediterranean Archaeology and Archaeometry 16, DOI:10.5281/zenodo.160965

4. Whitbread IK (1995) Greek transport amphorae: A petrological and Archaeological study. The British School at Athens, Fitch Laboratory. Athens.

5. Riccardi MP, Messiga B, Duminuco P (1999) An approach to the dynamics of clay firing, Applied Clay Science 15: 393-409.

6. Cultrone G, Rodriguez NC, Sebastian E, Cazalla O, De La Torre MJ (2001) Carbonate and silicate phase reactions during ceramic firing. Eur J Mineral 13: 621-634.

This work is licensed under Creative
7. Tite MS, Maniatis Y (1975) Examination of ancient pottery using the scanning electron microscope. Nature 257: 122-123

8. Barone G, Lo Giudice A, Mazzoleni P, Pezzino A (2005) Chemical characterization and statistical multivariate analysis of ancient pottery from Messina, Catania, Lentini and Siracusa (Sicily) Archaeometry 47: 745-762.

9. Barone G, Mazzoleni P, Aquilia E, Barbera G (2014) The Hellenistic and Roman Syracuse (Sicily) fine pottery production explored by chemical and petrographic analysis Archaeometry 56(1): 70-87.

10. Aquilia E, Barone G, Mazzoleni P, Raneri S, Lamagna G (2015) Petroarchaeometric characterization of potteries from a kiln in Adrano, Sicily. Heritage Science 12(3): 11.

11. Barone G, Di Bella M, Mastelloni MA, Mazzoleni P, Quartieri S, et al. (2017) Pigments characterization of polychrome vases production at Lipára: new insights by non-invasive spectroscopic methods. X-Ray spectrometry $10.1002 / x r s .2810$

12. Botti A, Ricci MA, De Rossi G, Kockelmann W, Sodo A (2006) Methodical aspects of SANS and TOF neutron diffraction measurements on pottery. The case of Miseno and Cuma. J Archaeol Sci 33: 307-319.

13. Barone G, Crupi V, Majolino D, Mazzoleni P, Teixeira J, et al. (2011b) Small angle neutron scattering as fingerprinting of ancient potteries from Sicily (Southern Italy). Applied Clay Science 54: 40-46.

14. Raneri S, Barone G, Crupi V, Longo F, Majolino D, et al. (2015) Technological analysis of Sicilian prehistoric pottery production through small angle neutron scattering technique. Periodico di Mineralogia 84(1): 1-22.

\section{Your next submission with Juniper Publishers will reach you the below assets}

- Quality Editorial service

- Swift Peer Review

- Reprints availability

- E-prints Service

- Manuscript Podcast for convenient understanding

- Global attainment for your research

- Manuscript accessibility in different formats

( Pdf, E-pub, Full Text, Audio)

- Unceasing customer service

Track the below URL for one-step submission https://juniperpublishers.com/online-submission.php 